\title{
READING BY DESIGN
}

The Visual Interfaces of the

English Renaissance Book 
This page intentionally left blank 


\section{PAULINE REID}

\section{Reading by Design}

The Visual Interfaces of the English Renaissance Book

UNIVERSITY OF TORONTO PRESS

Toronto Buffalo London 
(C) University of Toronto Press 2019

Toronto Buffalo London

utorontopress.com

Printed in the U.S.A.

ISBN 978-1-4875-0069-6

(@) Printed on acid-free, paper with vegetable-based inks.

\section{Library and Archives Canada Cataloguing in Publication}

Title: Reading by design : the visual interfaces of the English Renaissance book / Pauline Reid.

Names: Reid, Pauline, 1985- author.

Description: Includes bibliographical references and index.

Identifiers: Canadiana 20189066458 | ISBN 9781487500696 (hardcover)

Subjects: LCSH: Books and reading - England - History - 16th century. |

LCSH: Books and reading - England - History - 17th century. | LCSH:

Early printed books - England - 16th century. | LCSH: Early printed books - England - 17th century. | LCSH: Literature publishing England - 16th century. | LCSH: Literature publishing - England 17th century. | LCSH: Visual perception - History - 16th century. | LCSH: Visual perception - History - 17th century. | LCSH: English literature - Early modern, 1500-1700 - History and criticism. Classification: LCC Z1003.5.G7 R45 2019 | DDC 002.094209/031-dc23

University of Toronto Press acknowledges the financial assistance to its publishing program of the Canada Council for the Arts and the Ontario Arts Council, an agency of the Government of Ontario.

Canada Council for the Arts
Conseil des Arts du Canada 
For my husband 
This page intentionally left blank 